\title{
Gingival Overgrowth as a Complication of Kidney Transplantation - Nepali Perspective
}

\author{
Swosti Thapa ${ }^{1}$, Robin Bahadur Basnet ${ }^{2}$ Bikal Shrestha ${ }^{3}$, Amresh Thakur ${ }^{4}$, Neesha \\ Shrestha ${ }^{5}$, Anup Lal Shrestha ${ }^{6}$, Nabin Bahadur Basnet ${ }^{7}$ \\ ${ }^{1}$ Department of Burn, Plastic, and Reconstructive Surgery, Kirtipur Hospital, Kirtipur, Nepal
}

${ }^{2}$ Department of Urology, National Academy of Medical Sciences, Bir Hospital, Kathmandu, Nepal

${ }^{3}$ Department of Conservative and Endodontics, Nepal Police Hospital, Kathmandu, Nepal

${ }^{4}$ Department of Orthodontics and Dentofacial Orthopaedics, Nepal Armed Police Hospital, Kathmandu, Nepal

${ }^{5}$ Department of Dental Surgery, Kanti Children's Hospital, Kathmandu, Nepal

${ }^{6}$ Orthodontics and Dentofacial Orthopaedics

${ }^{7}$ Department of Nephrology and Transplantation, Sumeru Hospital, Lalitpur, Nepal

\begin{abstract}
Gingival Overgrowth is a known and common complication with multifactorial etiology seen in kidney transplant recipients. Gingival Overgrowth is induced in kidney transplant recipients by Cyclosporin A and Calcium Channel Blockers that are frequently prescribed to them as immunosuppressive and antihypertensive, respectively. There have been 1477 kidney transplantations in Nepal since the first kidney transplantation in 2008, but cases of gingival overgrowth have not been reported in any publications. The aim of this review is to discuss the different aspects of gingival overgrowth and its relevance to kidney transplant recipients of Nepal. This review will emphasize the need to examine the oral cavity of kidney transplant recipients. Genetic predisposition, oral health, and offending drugs are involved in the pathogenesis of gingival overgrowth. This review discusses the pathogenesis, clinical features, and management aspects of gingival overgrowth in kidney transplantation recipients. The reason for gingival overgrowth not being reported in Nepal could be due to various reasons like favorable genes, good oral hygiene, or avoidance of drugs that cause gingival overgrowth in kidney transplantation recipients. This could also be due to gingival overgrowth being ignored by the patients and the treating doctors. These aspects are reviewed with reference to previous publications.
\end{abstract}

Keywords: Calcium channel blocker; Cyclosporine; gingival overgrowth; Kidney transplantation; Oral health

\section{Correspondence:}

Dr. Nabin Bahadur Basnet, MBBS, PhD

Department of Nephrology and Transplantation, Sumeru Hospital, Lalitpur, Nepal ORCID ID: 0000-0002-3382-8176

Email: dr.nabinbasnet@gmail.com

Submitted $: 15^{\text {th }}$ November 2019 Accepted : $20^{\text {th }}$ December 2019

Source of Support: None Conflict of Interest: No

Citation: Thapa S, Basnet RB, Shrestha B, Thakur A, Shrestha N, Shresth AL, Basnet NB., Gingival Overgrowth as a complication of kidney transplantation - Nepalese perspective. NMJ 2019;2 (2): 259-64. DOI 10.3126/nmj.v2i2.26463

\section{INTRODUCTION}

Kidney transplantation is the best form of renal replacement therapy for eligible end-stage kidney disease (ESKD) patients. The first successful kidney transplantation was done in Boston between identical twins on December 23, 1954. In Nepal, the first successful kidney transplantation was achieved on August 8, 2008, at Tribhuvan University Teaching Hospital. ${ }^{1}$ From then to now, there have been 1477 kidney transplantations in seven centers in Nepal (Table 1). Other than these, Nepali patients with ESKD also travel to other countries for kidney transplantation. In 2008, Karki S. reported 452 kidney transplant recipients who had undergone transplantations in India, Germany, and the United States of America attending a single transplant follow-up clinic 
between June 16, 2003, to June 15, 2008. ${ }^{2}$ Though this trend must have been decreased by successful kidney transplantation programs in Nepal, it has not been verified; and apparently, there are still a good number of ESKD patients who travel to foreign countries for kidney transplantation. So, the number of kidney transplant recipients in Nepal can be projected to be much higher.

Table 1: Number of kidney transplantations done in various centers of Nepal from August 2008 to October, 2019

\begin{tabular}{ll}
\hline Centre & $\begin{array}{l}\text { Number of Kidney } \\
\text { Transplantations }\end{array}$ \\
\hline $\begin{array}{l}\text { Sahid Dharmabhakta National } \\
\text { Transplantation Center, Bhaktapur }\end{array}$ & 673 \\
\hline $\begin{array}{l}\text { Tribhuvan University Teaching Hospital, } \\
\text { Kathmandu }\end{array}$ & 591 \\
\hline Bir Hospital, Kathmandu & 150 \\
\hline Grande International Hospital, Kathmandu & 51 \\
\hline Sumeru Hospital, Lalitpur & 4 \\
\hline Nidan Hospital, Lalitpur & 4 \\
\hline College of Medical Sciences, Chitwan & 3 \\
\hline
\end{tabular}

The recipients of kidney transplantation are susceptible to a number of known complications due to underlying kidney disease, immunosuppression, and medicines prescribed to them. Two studies done in kidney transplant recipients of $\mathrm{TUTH}^{3,4}$ enumerates a number of surgical and non-surgical complications seen in Nepali kidney recipients. Though there are a vast number of complications that the recipients are at risk of, this review is limited to gingival overgrowth (GO). To best of our knowledge, there is no study or case report about oral cavity lesions in Nepali kidney transplant recipients. Among the 26 medical complications observed in the first 250 living donor kidney transplant recipients at TUTH, 2.7\% had an aphthous ulcer and 2.2\% had gum hypertrophy. These were the only two oral lesions so far reported in publication though oral lesions as listed in Table 2 are common complications seen in kidney transplant recipients. ${ }^{5,6}$

Table 2: Oral cavity lesions seen in kidney transplant recipient

\section{Infections}

a) Viral infections - herpes simplex virus, Varicellazoster virus, Cytomegalovirus, and Epstein Barr virus

b) Fungal infections - candida

c) Bacterial infections

\section{Lip and Oral Cancers}

3. Post-transplantation lymphoproliferative disorders

\section{Oral ulcerations}

\section{Oral lichenoid reactions}

6. Gingival Overgrowth

Oral health, especially periodontal, is adversely affected by consequences of kidney transplantation, and poor periodontal health negatively affects the clinical outcomes of kidney transplantation. ${ }^{7}$ This review is intended to discuss GO, which is overlooked in clinical practice, as an important oral cavity complication of kidney transplantation recipients.
EPIDEMIOLOGY AND CAUSATION OF GINGIVAL OVERGROWTH IN RENAL TRANSPLANTATION

GO refers to the abnormal growth of gingival tissue and is one of the commonest oral lesions seen in kidney transplant recipients. ${ }^{5-11}$ "Overgrowth' has replaced previously used terms 'hypertrophy' or 'hyperplasia' as histologically there are no obvious features of hypertrophy nor hyperplasia in GO. GO can be drug-induced, hereditary, or metabolic. This condition is under-recognized but can be caused by immunosuppressive and antihypertensive drugs frequently prescribed to kidney transplantation recipients (KTR). The incidence of GO in transplantation has been reported to be from $17.9 \%$ to $90 \%$ in various studies (Table 3 ).

Table 3: Prevalence of Gingival Overgrowth in Kidney Transplant Recipients

\begin{tabular}{llll}
\hline Studies & $\begin{array}{l}\text { Total No of } \\
\text { KTR }\end{array}$ & CsA & Tac \\
\hline Cezário $^{10}(2008)$ & 135 & $60 \%$ & $28.9 \%$ \\
\hline $\begin{array}{l}\text { de Oliveira Costa } \\
(2006)\end{array}$ & 545 & $38.1 \%$ & $17.9 \%$ \\
\hline
\end{tabular}

\begin{tabular}{|c|c|c|c|}
\hline Studies & $\begin{array}{l}\text { Total No of } \\
\text { KTR }\end{array}$ & CsA & $\mathrm{CCB}+\mathrm{CsA}$ \\
\hline Ghafari $^{8}(2010)$ & 200 & $35.00 \%$ & $\begin{array}{lc}50.00 \% & \text { Diltiazem } \\
44.00 \% & \text { Nifedipine }\end{array}$ \\
\hline Cebeci $^{12}(1996)$ & 51 & $40.91 \%$ & $51.72 \quad$ Verapamil \\
\hline $\begin{array}{l}\text { López-Pintor }{ }^{13} \\
(2009)\end{array}$ & 93 & $51.6 \%$ & $\begin{array}{ll}90.30 \% & \text { Nifedipine } \\
58.10 \% & \text { Amlodipine }\end{array}$ \\
\hline Khoori $^{14}(2003)$ & 119 & $56.00 \%$ & $90.00 \% \quad$ Nifedipine \\
\hline $\begin{array}{l}\text { Radwan- } \\
\text { Oczko }^{15}(2003)\end{array}$ & 124 & $46.00 \%$ & $\begin{array}{lc}86.00 \% & \text { Nifedipine } \\
47.00 \% & \text { Amlodipine } \\
35.00 \% & \text { Verapamil }\end{array}$ \\
\hline
\end{tabular}

Drug-induced GO (DIGO) was first recognized in children treated with phenytoin in $1939 .{ }^{16}$ Three classes of drugs are known to be associated with GO as shown in Table $4 .{ }^{17}$ Drugs frequently prescribed to kidney transplantation recipients that are implicated as causing GO are - Cyclosporine A (CsA) and Calcium Channel Blockers (CCB).

Table 4: Three classes of drugs associated with drug-induced GO

1. Anticonvulsant - Phenytoin,

2. Immunosuppresants - CsA, Tacrolimus, Sirolimus

3. Calcium Channel Blocker - Nifedipine, Amlodipine, Verapamil, and Diltiazem

CsA is a calcineurin inhibitor (CNI) that has been in use as an immunosuppressive agent in kidney transplantation since the early 1980s. ${ }^{18}$ It is known to be associated with various complications including GO which has been reported to be present in 25 to $80 \%$ of the patients on CsA. Most of the transplant recipients in Nepal are prescribed newer CNI, Tacrolimus, which has a lower incidence of GO. ${ }^{9-11,19}$ Tacrolimus has largely replaced $\mathrm{CsA}^{18}$ because of a better side-effect profile. CsA is still used in Nepal due to the cost-benefit and also in diabetic kidney transplant recipients. ${ }^{20}$ 
Amlodipine and Nifedipine are two CCB that are frequently seen in prescriptions of ESKD patients for blood pressure control and other advantages of this class of drugs. ${ }^{21}$ These are also preferred after the transplantation as they attenuate nephrotoxicity of CNI prescribed to the kidney transplant recipients. ${ }^{22}$ Diltiazem is another CCB that is added by the nephrologists when the level of $\mathrm{CNI}$ are less than the target. It is an antihypertensive medicine but interacts with the metabolism of CNI increasing the serum levels of the CNI. ${ }^{23}$ All of these CCBs are associated with GO. ${ }^{24}$ CCBinduced GO in Nepal have been reported in three publications ${ }^{25-27}$ though none included patients with kidney disease nor kidney transplantation. The first study done in a period of six months reported GO in 122 out of 150 patients on antihypertensive medication. There was a higher prevalence in patients taking CCB (71.1\%) than Angiotensin-Converting Enzyme Inhibitor (21.5\%), and Beta-Blockers (7.4\%). ${ }^{25}$ The second study ${ }^{26}$ recruited 250 patients on antihypertensive medication attending a tertiary care hospital. However, the prevalence of GO was totally different. Only $2.5 \%$ of the patients had GO, and all of them were on Amlodipine. The third study ${ }^{27}$ discussed a case of Amlodipineinduced GO that was treated by conservative approach, drug substitution, and surgery. The difference in prevalence in the first two studies could be due to the difference in oral hygiene between the population or due to under- or over-diagnosis in the studies.

GO in kidney transplant recipients in Nepal has not been reported in any publication. The rarity of cases of GO in Nepali kidney transplant recipients could be due to under-appreciation by treating doctors, rigorous oral hygiene program, or use of Tacrolimus in most of the patients.

\section{PATHOPHYSIOLOGY}

The pathogenesis of GO is not completely understood. It is said to be multifactorial ${ }^{28}$ where various factors like age, sex, state of inflammation and cytokine release ${ }^{28,29}$ (including IL-6, IL-8, IL$1 \beta$, IL-1 $\beta 1$, and PGE2) biochemical factors, and genetic factors affect the genetic expression of gingival fibroblasts. ${ }^{28}$ In the animal model, drug-induced GO was seen to be dose-dependent, more severe in male and young, regress after discontinuation of the drug, and severe in those with pre-existing gingival inflammation. ${ }^{30}$ Similar risk factors are said to exist also in kidney transplantation recipients with GO.

Seymour reviewed the pathogenesis of GO in 1996 as interaction between various factors where the presence of certain threshold concentration of the drug was required to 'activate' the overgrowth in patients with certain risk factors of age and genetic predisposition for drug-induced alterations in gingival connective tissue $^{28}$ More recently in 2015, Trackman ${ }^{31}$ explored molecular and cellular aspects of DIGO and stated that it differs considerably as a function of causative drug. The basic difference between the different drugs was the degree of inflammation and fibrosis. CsAinduced GO has more inflammation and little fibrosis while CCBinduced and Phenytoin-induced GO are more fibrotic. ${ }^{32} \mathrm{CsA}$ also inhibits collagenolytic activity. ${ }^{33} \mathrm{CCB}$ potentiates the effect of CsA. ${ }^{14}$

\section{CLINICAL FEATURES AND DIAGNOSIS}

GO develops insidiously in patients with risk factors within 1 to 3 months of initiation of the causative drug. Many of the kidney transplant recipients have coexisting hypertension for a long period of time prior to the transplantation. CsA is initiated at the time of kidney transplantation. The onset and the course are insidious and the patient remains asymptomatic in mild to moderate severity of the disease. It may be associated with pain, swelling, and bleeding if associated with poor oral hygiene and dental plaques. As the severity of the condition increases, GO hampers normal oral functions such as chewing and speech and worsens oral hygiene. Halitosis may be present due to dental plaque and food accumulation.

Oral cavity examination will show the presence of GO in the labial gingival mucosa and the interdental papillae area. CsA-induced GO starts as a papillary enlargement that is most prominent on the labial aspects of the gingiva. These papillary enlargements then increase and appear to coalesce which gives the gingival tissues a lobulated appearance. It is also most prominent in the region where there are orthodontic appliances but rare in edentulous areas. Distribution is usually symmetrical. Gingiva appears thickened and lobulated because of the enlargement of the gingival tissue. Bleeding tendency and inflammation may be seen if the tissue is highly vascularized due to other periodontal pathology. GO covers the tooth surface including the occlusal surface and may extend into the sulcus. ${ }^{24}$ There are various classifications and indices to express the extent and severity of the disease. ${ }^{34}$ These are applied to describe the lesions, decide the management plans, and also to monitor the improvement with the treatment.

Diagnosis is by clinical history and examination. Imaging is important for treatment planning and analyzes the risk factors for GO. Periapical or panoramic view radiographs should be done at the start of the treatment. Tissue biopsy is indicated if there is an unusual clinical presentation or the cause is not apparent. Histology of the tissue will show an increase in extracellular tissue volume than the number of cells. The epithelium overlying the area will show variable thickening, irregularity, and multiple layers. It has been reported with acanthosis and parakeratosis with pseudoepitheliomatous proliferation. In the presence of inflammation, the biopsy will show highly vascular connective tissue with an accumulation of inflammatory cells. Langerhans cells within the epithelium and adjacent to inflamed areas may be seen in immunohistochemistry.

\section{MANAGEMENT}

\section{Prevention}

DIGO can only be prevented by avoiding the drug that are known to be associated with $\mathrm{GO}^{35}$. This might not be possible in clinical practice. The risk can be reduced by controlling local factors and maintaining oral hygiene. ${ }^{36,37}$ The patients should be on 3 to 6 monthly periodontal maintenance therapy.

\section{Treatment}

Treatment of GO needs a multidisciplinary approach with the involvement of the dental surgeon and transplantation team. Components of treatment are

1. Drug adjustment - substitution or withdrawal

2. Non-surgical conservative treatment

3. Surgical Periodontal Treatment 
Mild GO will improve with local conservative management which consists of removal of plaque and calculus deposits. This approach comprises maintaining good oral hygiene and professional dental cleaning. This resolves the inflammation and GO will subside..$^{24,38}$

The conservative approach will not be sufficient for the management of the severe form of DIGO. This may require a reduction of dose or substitution or withdrawal of the offending drug. It will take 6 to 12 months for the resolution of the lesion. Drug adjustment is the most effective treatment of DIGO. Conversion of CsA to Tacrolimus effectively improves $\mathrm{GO}^{16-}$ 18 though Tacrolimus, usually with previous use of CsA or concurrent use of CCB, has also been shown to be associated with GO. ${ }^{9-11,19}$ Similarly, CCBs can be changed to other classes of antihypertensives along with measures to control plaque and calculus. ${ }^{42}$ The use of antibiotics is controversial with some in favor of use for a short term ${ }^{43,44}$ while others mention it as having equivocal efficacy. ${ }^{45}$ Azithromycin in combination with other conservative interventions is said to induce a striking reduction in CsA-induced GO than conservative interventions alone. ${ }^{46}$ The mechanism by which Azithromycin is effective for the remission of CsA induced GO is different from its antibiotic properties. Azithromycin blocks CsA-induced cell proliferation and collagen synthesis and activates metalloproteinase- 2 in gingival fibroblasts. ${ }^{47}$ Improvement is apparent after a few days of drug adjustment.

Surgical removal is the only treatment for those who develop GO even after prophylactic measures and discontinuation or substitution of the offending drug are not effective. It can be done by gingivectomy and flap operation. Gingivectomy is done with carbon dioxide, YAG, lower-level laser therapy, photobiomodulation diode laser ${ }^{44}$, or dual-wavelength laser treatments and is followed by rinsing with Chlorhexidine $0.2 \%$ for the next few days. ${ }^{24}$ Removal of excessive tissue heals the disease faster and is associated with only mild discomfort. GO notoriously relapses in $34 \%$ of the patients 18 months after periodontal surgery. ${ }^{48}$ Follow-up cares for up to 18 months for surgical care improves the outcome of the management. ${ }^{48}$ Efforts suggested to reduce the risk of recurrence are the maintenance of good oral hygiene, the use of Chlorhexidine gluconate, the substitution of CsA and CCB with other medications, frequent professional recall appointments, and hygienic design of dental prosthetics. $^{44}$

\section{GO IN NEPALI PERSPECTIVE}

GO or DIGO is fairly common among kidney transplant recipients as reported in previous studies from different centers around the world. It has already been a decade of successful transplantation in Nepal with 1477 kidney transplantations. Most of the patients are on CCBs as antihypertensive and receiving either Tacrolimus or CsA in the immunosuppressive regimen. However, only 6 patients of kidney transplantation have been reported to have "gum hypertrophy" in Nepal.

GO as discussed occurs in genetically predisposed individuals who have risk factors and exposure to certain drugs. A paucity of reports from Nepal on GO could be due to favorable genes that protect the patients from $\mathrm{GO}$, good oral hygiene among the patients, less use or low dose of medications used, or under-diagnosis of the conditions by the doctors. A genetic predisposition for GO is poorly understood. With this background, it is not possible to discuss whether genetic factors are responsible for the rarity of GO among kidney transplant recipients in Nepal.

Nepal is a low-income country and is expected to lag behind in oral health and hygiene than other developed countries due to limited resources, knowledge, and accessibility to oral health care. Knowledge, attitude, practice, and state of oral health of ESKD patients and kidney transplantation recipients has not been studied in Nepal. A study published in June 2018 of women in rural Nepal showed that the Nepalese women had the knowledge and had a good practice of maintaining oral hygiene but did not have knowledge and accessibility to oral health care. ${ }^{49} \mathrm{~A}$ similar finding was published in $2016^{50}$ where 4200 adults were recruited. The study also showed good knowledge and practice of oral hygiene but lack of knowledge and practice of visiting a dentist. Overall, the available reports showed unsatisfactory oral health and hygiene status in Nepal. It is, therefore, not correct to say Nepali are protected from GO because of good oral health. It can be argued that the kidney transplant recipients are subjected to rigorous pre-transplantation workup that also includes oral health evaluation and interventions to improve the condition by the professional. However, from the evidence discussed it is clear that maintaining oral hygiene may reduce the severity and also hastens the healing but cannot prevent GO. ${ }^{36}$

Kidney transplant recipients mostly receive Tacrolimus as CNI of choice. Some are prescribed CsA instead due to various indications. Most are also prescribed CCBs for blood pressure control or maintain blood levels of CNIs. So, among 1477 kidney transplant recipients even if we expect the least number of patients having GO, almost 100 recipients might be having GO in Nepal. TUTH reported 6 patients but at least three times the number is expected to have GO. Underdiagnosis can be one of the causes. As the condition, most of the time is insidious, patients not reporting the problems to the doctors and not visiting the professional regularly while doctors ignoring to do the oral examination and failing to keep the records may be the reason for under-reporting of GO in publications.

\section{CONCLUSIONS}

Kidney transplant recipients are vulnerable to many complications due to the prescribed drugs and associated immunosuppression. DIGO is a common but often overlooked condition. GO is a preventable condition with multifactorial etiology. Treating physicians should be vigilant and oral examination should be a part of an examination of kidney transplant recipients. Maintenance of oral hygiene should be emphasized and proper instructions given including regular visits to dentists for professional management of oral hygiene. If a recipient develops GO, the treatment should be multidisciplinary for a better outcome and will need a regular followup with a dental surgeon for reducing the risk of relapse of the condition. 


\section{REFERENCES}

1. Chalise PR, Shah DS, Sharma UK, Shrestha GK, Joshi BR, Kafle MP et al. Renal transplantation in Nepal: the first year's experience. Saudi J Kidney Dis Transpl. 2010;21(3):559-64. Crossref

2. Nepalese kidney transplant recipient in a follow up clinic: related and unrelated living donor. JNMA J Nepal Med Assoc. 2008;47(171):98103. $\underline{\text { Crossref }}$

3. Shrestha S. Renal Transplant in Nepal: Medical Complications in First Three Months. Vol 35.; 2013. Crossref

4. Kafle M, Shah DS. Medical Complications in Living Donor Kidney Transplant Recipients in the Developing World. Transplantation. 2018;102:S633. Crossref

5. da Silva LCF, de Almeida Freitas R, de Andrade MP, Piva MR, Martins-Filho PRS, de Santana Santos T. Oral lesions in renal transplant. J Craniofac Surg. 2012;23(3):e214-8. Crossref

6. Patil S, Maheshwari S, Wadhawan R, Kaswan S. Prevalence of oral lesions in kidney transplant patients: A single center experience. Saudi J Kidney Dis Transplant. 2015;26(4):678. Crossref

7. Nunes-dos-Santos DL, Gomes S V., Rodrigues VP, Pereira ALA. Periodontal status and clinical outcomes in kidney transplant recipients: A systematic review. Oral Dis. 2019. Crossref

8. Ghafari A, Poorabbas R, Takieh JA, Sepehrvand N, Kargar C, Hatami S. Gingival enlargement and its risk factors in kidney transplant patients receiving cyclosporine A. Iran J Kidney Dis. 2010;4(1):66-70. $\underline{\text { Crossref }}$

9. Greenberg KV., Armitage GC, Shiboski CH. Gingival enlargement among renal transplant recipients in the era of new-generation immunosuppressants. J Periodontol. 2008;79(3):453-60. Crossref

10. Cezário ES, Cota LOM, Ferreira SD, Siqueira FM, Soares RV, Zenobio EG, Costa FO. Gingival overgrowth in renal transplant subjects medicated with tacrolimus in the absence of calcium channel blockers. Transplantation. 2008;85(2):232-6. Crossref

11. de Oliveira Costa F, Diniz Ferreira S, de Miranda Cota LO, da Costa JE, Aguiar MA. Prevalence, Severity, and Risk Variables Associated With Gingival Overgrowth in Renal Transplant Subjects Treated Under Tacrolimus or Cyclosporin Regimens. J Periodontol. 2006;77(6):969-75. Crossref

12. Cebeci I, Kantarci A, Firatli E, Çarin M, Tuncer Ö. The Effect of Verapamil on the Prevalence and Severity of Cyclosporine-Induced Gingival Overgrowth in Renal Allograft Recipients. J Periodontol. 1996;67(11):1201-5. Crossref

13. López-Pintor RM, Hernández G, de Arriba L, Morales JM, Jiménez $\mathrm{C}$, de Andrés A. Amlodipine and Nifedipine Used With Cyclosporine Induce Different Effects on Gingival Enlargement. Transplant Proc. 2009;41(6):2351-3. $\underline{\text { Crossref }}$

14. Khoori AH, Einollahi B, Ansari G, Moozeh MB. The effect of cyclosporine with and without nifedipine on gingival overgrowth in renal transplant patients. J Can Dent Assoc. 2003;69(4):236-41. Crossref

15. Radwan-Oczko M, Boratyńska M, Klinger M, Zietek M. Risk factors of gingival overgrowth in kidney transplant recipients treated with cyclosporine A. Ann Transplant. 2003;8(4):57-62.

16. Kimball OP. The treatment of epilepsy with sodium diphenyl hydantoinate. J Am Med Assoc. 1939;112(13):1244-1245. Crossref

17. Informational Paper: Drug-Associated Gingival Enlargement. J Periodontol. 2004;75(10):1424-31. $\underline{\text { Crossref }}$

18. Lloveras J. Use of cyclosporine in renal transplantation. Transplant Proc. 2004;36(2 SUPPL.):S107-13. Crossref

19. Cota LOM, Aquino DR, Franco GCN, Cortelli JR, Cortelli SC, Costa FO. Gingival overgrowth in subjects under immunosuppressive regimens based on cyclosporine, tacrolimus, or sirolimus. J Clin Periodontol. 2010;37(10):894-902. Crossref

20. Hada, Prasad N, Baral A, Agrawal RK. Outcome of live donor kidney transplantation in a Government Hospital of Nepal. Indian J Transplant. 2017;11(2):55. Crossref

21. Georgianos PI, Agarwal R. Pharmacotherapy of hypertension in chronic dialysis patients. Clin J Am Soc Nephrol. 2016;11(11):206275. Crossref

22. Jensen RR, Healy RM, Ford CD, et al. Amlodipine and calcineurin inhibitor-induced nephrotoxicity following allogeneic hematopoietic stem cell transplant. Clin Transplant. 2019;33(7) :e13633. Crossref

23. Brockmöller J, Neumayer HH, Wagner K, Weber W, Heinemeyer G, Kewitz H, Roots I. Pharmacokinetic interaction between cyclosporin and diltiazem. Eur J Clin Pharmacol. 1990;38(3):237-42. Crossref

24. Taylor BA. Management of drug-induced gingival enlargement. Aust Prescr. 2003;26(1):11-3. Crossref

25. Pradhan S, Mishra P. Gingival enlargement in antihypertensive medication. J Nepal Med Assoc. 2009;48(174):149-52. Crossref

26. Sharma A, Joshi R, Laxmi Rana SR, Shrestha DB, Joshi PR, Khadka S. Amlodipine induced Gingival Overgrowth in Patients at a Tertiary Level Hospital of Nepal. J Nepal Soc Periodontol Oral Implantol. 2018;2(1):2-5. Crossref

27. Koirala PK, Pradhan S, Gorkhali RS. Gingival Enlargement Management in Bir Hospital - A Case Series. J Nepal Soc Periodontol Oral Implantol. 2017;1(2):84-90. Crossref

28. Seymour RA, Thomason JM, Ellis JS. The pathogenesis of druginduced gingival overgrowth. J Clin Periodontol. 1996;23(3):16575. $\underline{\text { Crossref }}$

29. Salman BN, Vahabi S, Movaghar SE, Mahjour F. Proliferative and inductive effects of Cyclosporine a on gingival fibroblast of child and adult. Dent Res J (Isfahan). 2013;10(1):520-8. Crossref

30. Nishikawa S, Nagata T, Morisaki I, Oka T, Ishida H. Pathogenesis of Drug-Induced Gingival Overgrowth. A Review of Studies in the Rat Model. J Periodontol. 1996;67(5):463-71. Crossref

31. Trackman PC, Kantarci A. Molecular and clinical aspects of drug-induced gingival overgrowth. J Dent Res. 2015;94(4):540-6. Crossref

32. Uzel MI, Kantarci A, Hong H-H, et al. Connective Tissue Growth 
Factor in Drug-Induced Gingival Overgrowth. J Periodontol. 2001;72(7):921-31. Crossref

33. Hyland PL, Traynor PS, Myrillas TT, et al. The Effects of Cyclosporin on the Collagenolytic Activity of Gingival Fibroblasts. J Periodontol. 2003;74(4):437-45. Crossref

34. Dubey S, Gattani D, Deotale S, Quazi M, Student PG. A contemporary review on indices for gingival enlargement. J Adv Med Dent Scie Res 2016;4(4):62-7. Crossref

35. Hall EE. Prevention and treatment considerations in patients with drug-induced gingival enlargement. Curr Opin Periodontol. 1997;4:59-63.

36. Seymour RA, Smith DG. The effect of a plaque control programme on the incidence and severity of cyclosporin-induced gingival changes. J Clin Periodontol. 1991;18(2):107-10. Crossref

37. Pejcic A, Djordjevic V, Kojovic D, et al. Effect of periodontal treatment in renal transplant recipients. Med Princ Pract. 2014;23(2):149-53. $\underline{\text { Crossref }}$

38. Pundir AJ, Pundir S, Yeltiwar RK, Farista S, Gopinath V, Srinivas TS. Treatment of drug-induced gingival overgrowth by full-mouth disinfection: A non-surgical approach. J Indian Soc Periodontol. 2014;18(3):311-5. Crossref

39. James JA, Boomer S, Maxwell AP, et al. Reduction in gingival overgrowth associated with conversion from cyclosporin A to tacrolimus. J Clin Periodontol. 2000;27(2):144-8. Crossref

40. Hernández G, Arriba L, Lucas M, de Andrés A. Reduction of Severe Gingival Overgrowth in a Kidney Transplant Patient by Replacing Cyclosporin A With Tacrolimus. J Periodontol. 2000;71(10):1630-6. $\underline{\text { Crossref }}$

41. Hernández G, Arriba L, Cruz Frías M, et al. Conversion from Cyclosporin A to Tacrolimus as a Non-Surgical Alternative to Reduce Gingival Enlargement: A Preliminary Case Series. J Periodontol. 2003;74(12):1816-23. Crossref
42. Dhale R, Phadnaik M. Conservative management of amlodipine influenced gingival enlargement. J Indian Soc Periodontol. 2009;13(1):41. Crossref

43. Wong W, Hodge MG, Lewis A, Sharpstone P, Kingswood JC. Resolution of cyclosporin-induced gingival hypertrophy with metronidazole. Lancet (London, England). 1994;343(8903):986. Crossref

44. Aral CA, Dilber E, Aral K, Sarıca Y, Sivrikoz ON. Management of cyclosporine and nifedipine-induced gingival hyperplasia. J Clin Diagnostic Res. 2015;9(12):ZD12-5. Crossref

45. Mavrogiannis M, Ellis JS, Thomason JM, Seymour RA. The management of drug-induced gingival overgrowth. J Clin Periodontol. 2006;33(6):434-9. Crossref

46. Ramalho VLC, Ramalho HJ, Cipullo JP, Azoubel R, Burdmann EA. Comparison of Azithromycin and Oral Hygiene Program in the Treatment of Cyclosporine-Induced Gingival Hyperplasia. Ren Fail. 2007;29(3):265-70. Crossref

47. Kim JY, Park SH, Cho KS, et al. Mechanism of azithromycin treatment on gingival overgrowth. J Dent Res. 2008;87(11):1075-9. $\underline{\text { Crossref }}$

48. Ilgenli T, Atilla G, Baylas H. Effectiveness of Periodontal Therapy in Patients With Drug-Induced Gingival Overgrowth. Long-Term Results. J Periodontol. 1999;70(9):967-72. Crossref

49. Lubon AJ, Erchick DJ, Khatry SK, et al. Oral health knowledge, behavior, and care seeking among pregnant and recently-delivered women in rural Nepal: a qualitative study. BMC Oral Health. 2018;18(1):97. Crossref

50. Thapa P, Aryal KK, Mehata S, et al. Oral hygiene practices and their socio-demographic correlates among Nepalese adult: evidence from non communicable diseases risk factors STEPS survey Nepal 2013. BMC Oral Health. 2016;16(1):105. Crossref 